\title{
Poesía
}

\section{Lizardo Cruzado (Trujillo, 1975).}

Fruto de sus devaneos adolescentes con la poesía engendró el poemario "Este es mi cuerpo" (1996, y reeditado en el 2018). Actualmente se desempeña como médico psiquiatra en el Instituto Nacional de Salud Mental Honorio Delgado-Hideyo Noguchi y como profesor auxiliar en el Departamento de Clínicas Médicas de la Universidad Peruana Cayetano Heredia.

Reavivada su afición a componer versos, estos poemas corresponden a "No he de volver a escribir", que verá la luz en este año.

\section{Los NúMERos}

Esta libreta de tapas duras guardaba

Los teléfonos de todos tus amigos

Esta libreta era gorda como un libro pues

En la palabra amigos

Cabe cualquier conocido y

En ella también registrabas los números

De algunos enemigos:

Amigos que no se sabían nombrados

Enemigos y enemigos que tú

Ingenuamente creías tus amigos

Unidos todos por la espiral dorada y perfecta

Que atravesaba las páginas

Y que hoy igualmente las mantiene unidas

Pero perfectamente oxidada

Los años han ejecutado el prodigio

Y esos nombres de amigos para toda la vida

Al final meros circunstantes

Y partiquinos

Ahora

Solo son números

Han perdido su burda condición humana

Y así emergen números primos

Números matemáticamente amigos

Números sociables y hasta

Números perfectos

Haz la prueba y marca en el teléfono

Estas remotas cifras envejecidas

Una voz lustral dirá que los teléfonos

marcados
No existen

Y nada ya les arrebatará

Su pureza.

\section{Cualquier día de Febrero}

El ventilador que sorprendes en el

Techo girando veloz al

Abrir la puerta de una habitación vacía

No pide que lo apagues

Detente al pie de él

Siente

El frescor del silencioso ámbito

Acogiéndote

Esa brisa muda que esperaba por ti

Gratuitamente

Brizna de destino que acaricia tu piel

Fugaz trofeo

Del verano.

\section{La Luz}

Añoro aquella edad y el tiempo aquel

Cuando una linterna a pilas

Era el más mágico de los objetos mágicos

Y nuestra curiosidad podía abrir en dos al mundo como

A cualquier fruta madura a las cuatro de la tarde 
Añoro aquel verano y aquella tarde cuando Abrimos la linterna y extrajimos sus semillas Cilíndricas y frías en número de tres El arcano de la luz allí debía estar cifrado Con un martillo atacamos las pepas metálicas Intrépido afán

Esfuerzo hercúleo

Trajín titánico

Y en el piso del patio quedaron machacadas las pilas Rayovac

Sin que una gota de luz saltara

Codiciada recompensa

A nuestros ojos de expectativa y denuedo lacrimosos

Después la física y la química intentarían malograrlo todo

Aunque no pudieron

En la memoria fulguran aquellos días cuando Una opaca barra de grafito en un mazacote de carbón

Fue explicación suficiente y convincente

De toda la magia

De la luz.

\section{El Parque}

En la época cuando tuvimos deudas

Y debimos suprimir compras suntuarias y

Nuestros modestos derroches en el centro comercial

Empezamos a ir las tardes del domingo a Tendernos en el parque

Cerca de la casa

Para así ahorrar

Temíamos aburrirnos pero llegamos a descubrir
Hormigas que misteriosamente nunca se aburrían en el

Mismo rincón de un cantero de césped

Avistamos las humildes barriadas de los

pájaros

En las más altas ramas de los árboles

-asombrosamente muchas variedades de

pájaros y

varios tipos de árboles-

Con el agua de las mangueras sembrábamos

De destellos la yerba y la tierra seca por igual

Y lo más sorprendente de todo

Una estrella brillaba en el cielo de día

Nos esperaba hasta la tarde

Y siempre quería anidarse en nuestros ojos para cantar.

\section{Ars}

La poesía es hablar solo

Como los locos

Hablan

A veces con uno mismo

Gruñidos endechas

Tiernas palabrotas

Flatos verbales y

Silencios

A veces hablar

Con otro

Ferozmente alucinado

Imaginado

Inexistente

Pero usualmente

Más frecuentemente

Con absolutamente

Nadie. 